\title{
PROVA BRASIL E LEITURA NO LIVRO DIDÁTICO DE PORTUGUÊS - APROXIMAÇÕES OU DISTANCIAMENTOS?
}

\section{"PROVA BRASIL" AND READING IN TEXTBOOK OF PORTUGUESE - APPROXIMATIONS OR DETACHMENTS?}

\author{
Miriã Alves de Laet Silva ${ }^{56}$ \\ Sílvio Ribeiro da Silva ${ }^{57}$
}

\begin{abstract}
RESUMO: No contexto educacional, a leitura perpassa todas as disciplinas do Currículo. Tal fato é de fundamental importância, já que as atividades de leitura e interpretaçăo feitas pelos alunos devem favorecer o desenvolvimento dos letramentos (institucionalizados ou năo). Na escola, sua prática ocorre, na maioria das vezes, a partir do livro didático (LD) e este tem despertado o interesse dos pesquisadores que passaram a vê-lo como um importante integrante das práticas escolares. Levando em conta que as avaliaçôes sâo construídas tendo a leitura como ferramenta para medir as competências e habilidades do aluno, discute-se aqui se as propostas de leitura e interpretaçáo do texto escrito, apresentadas aos alunos pelo Livro Didático de Português - LDP - Tudo é linguagem, Ensino Fundamental II - anos finais, contemplam os descritores do Tópico V da Matriz de Referência de Língua Portuguesa da Prova Brasil, entendendo que o desenvolvimento das competências e habilidades, propostas pela matriz, coadunam com práticas significativas de leitura. Assim a intençâo foi perceber se há influência da avaliaçăo em larga escala na política de elaboraçâo de materiais didáticos, por mais que saibamos que, até o momento, nâo existe encaminhamento para que a avaliaçâo e o LDP sejam reflexo um do outro. 0 estudo apresenta caráter qualitativo-interpretativista, caracterizando-se como análise documental, sendo situado no campo da Educaçăo. Os resultados mostram que os descritores do Tópico V da Prova Brasil foram mobilizados na coleçâo, porém havendo discrepância quantitativa e qualitativa de ocorrência entre eles.
\end{abstract}

Palavras-chave: Leitura; Interpretaçăo de texto escrito; Livro Didático de Português; Prova Brasil.

ABSTRACT: In the educational context, the reading permeates all the subjects in the Curriculum. Such a fact is of fundamental importance, as the reading and interpretation activities done by the students should encourage the development of literacy (institutionalized or not). At school, your practice is, for the most part, from the textbook (TB) and this has aroused the interest of researchers who have come to

56 Universidade de Rio Verde (GO). Caiapônia. Mestre em Educaçăo. Assessora Pedagógica. email: mirialaet@hotmail.com

57 Universidade Federal de Goiás Regional Jataí. Doutor em Linguística Aplicada. Professor Adjunto 3. email: shivonda@gmail.com 
see it as an important member of the school practices. Given that evaluations are built with reading as a tool to measure the competencies and skills of the student, we discuss here the proposals for reading and interpretation of the written text, presented to the students by the Textbook of Portuguese (TBP) "Tudo é linguagem" Elementary School II - last years, include the topic V descriptors of the Portuguese Language Reference Matrix "Prova Brasil", understanding that the development of competences and abilities, proposed by the matrix, consistent with significant practical reading. So the intention was to see if there is evaluation of influence on a large scale in the preparation of teaching materials policy, however we know that, to date, there is no referral to the evaluation and the TBP are a reflection of each other. The study presents qualitativeinterpretative character, characterized as documentary analysis, being situated in the field of education. The results show that the Topic V descriptors "Prova Brasil" were mobilized in the collection, however there is quantitative and qualitative discrepancy of ocorrence among them.

Keywords: Reading; Interpretation of written text; Textbook of Portuguese; “Prova Brasil”

\section{PARA COMEÇO DE CONVERSA...}

Neste artigo, apresentamos resultados de uma investigaçăo que associou as atividades de leitura e interpretaçăo de textos escritos nas atividades propostas pelo livro didático de português e a Matriz de Referência da Prova Brasil (Língua Portuguesa). 0 objetivo que temos é mostrar se a Prova Brasil tem direcionado a forma como as práticas de leitura e interpretaçâo de textos escritos sâo apresentadas ao aluno no Livro Didático de Português (LDP).

Mesmo tendo plena consciência de que năo é objetivo da Prova Brasil interferir na forma como sâo organizados os livros didáticos, sabemos que esse tipo de avaliaçâo acaba por encaminhar a maneira como năo só os materiais didáticos serâo pensados, como também a forma como o currículo escolar é organizado.

Para o alcance do objetivo proposto, apresentamos um conjunto de atividades de leitura e interpretaçấo do LDP “Tudo é Linguagem", discutindo a mobilizaçâo feita dos descritores do Tópico V da Matriz de Referência da Prova Brasil. A justificativa para o estudo reside no fato de que as avaliaçôes em larga escala, como a Prova Brasil, são uma realidade no atual cenário da Educaçăo no país. Assim, intencionamos perceber até que ponto existe (ou se năo existe) influência da avaliaçăo em larga escala na política de elaboraçáo de materiais didáticos.

O LDP em estudo tem como autoras Ana Trinconi Borgatto, Terezinha Bertin e Vera Marchezi, sendo editado pela Ática. A coleçâo é composta por quatro volumes, que contemplam do sexto ao nono ano do Ensino Fundamental II. A coleçăo consta entre as aprovadas pelo PNLD no triênio 2011 - 2013 - e foi escolhida por oito dentre as vinte escolas (perfazendo um montante de 40\%) atendidas pela subsecretaria de Iporá Goiás, em 2011, ano de início do triênio desta coleçăo. ${ }^{58}$ A escolha desta regiâo se deve ao

58 Fundo Nacional de Desenvolvimento de Educaçăo. Disponível em: <https://www.fnde.gov.br/ distribuicaosimadnet/popularMunicipio>. Acesso em: 17 nov. 2016. 
fato de que Caiapônia-Go, onde residimos, é um município atendido pela subsecretaria há pouco referida. ${ }^{59}$ Dentre as escolas que adotaram este LDP, sete (um total de 85,5\%) obtiveram notas do Índice de Desenvolvimento da Educaçáo Básica (IDEB) ${ }^{60}$ - do $9^{\circ}$ ano do Ensino Fundamental - inferiores ao preconizado pelas metas do IDEB (4,1 para o ano de 2011 na regiăo), as quais foram criadas a partir de indicadores dos programas de avaliaçăo e objetivam elevar a média nacional ao valor 6,0 até $2021 .{ }^{61}$ Entăo, a escolha do tema leitura e interpretaçâo do texto escrito no LD da coleçấo ocorreu pelo fato de que vislumbramos nesse objeto de investigaçăo uma das possibilidades de compreensăo no campo do ensino e aprendizagem de leitura. Tal compreensâo resulta das orientaçóes de documentos (PCN 1998, Matrizes de Referência) que consideram a leitura fundamental para o desenvolvimento da aprendizagem em qualquer área do conhecimento, ideia com a qual compartilhamos.

Ler e interpretar um texto escrito sâo atos que só podem ser executados por um sujeito. Ao dizer isso, queremos deixar claro que atividades de mera decodificaçăo năo podem ser entendidas como leitura e interpretaçăo, isso porque văo na contramăo daquilo que entendemos como sendo leitura de fato. No nosso entendimento, aquele que realiza atividades com foco apenas na decodificaçâo é tăo somente um processador de informaçâo gráfica.

A açăo de ler e interpretar um texto é desenvolvida na relaçăo com o mundo, levando em conta que o processo de formaçáo do leitor se inicia no momento em que o indivíduo consegue atribuir sentido ao mundo que o cerca (FREIRE, 1989), atitude esta que vai sendo desenvolvida durante toda a vida. Assim, a prática da leitura, como ato reflexivo capaz de envolver a construçăo de sentidos pelo leitor, é um processo amplo, contínuo e ininterrupto. Em se tratando do ensino e aprendizagem da leitura, para que o leitor aprendiz possa desenvolver práticas relevantes, além de ser capaz de selecionar os textos de que necessita para interagir nos diversos contextos em que precise atuar (BRASIL, 1998), a sua formaçăo leitora deve proporcionar o desenvolvimento de capacidades de leitura, como a localizaçâo ou cópia de informaçôes, a checagem de hipóteses, a comparaçấo e a generalizaçăo (ROJO, 2009).

Considerando o espaço escolar e, especificamente, a sala de aula, como ambiente privilegiado de construçấo do conhecimento, faz-se necessário refletir sobre as atividades desenvolvidas e os recursos disponíveis para o trabalho docente neste espaço. Pensando assim, o livro didático (LD) torna-se importante ferramenta de análise acadêmica, uma vez que seu uso cotidiano é prática regular nas salas de aula brasileiras, possuindo, este, editoraçăo considerável, com altas tiragens do ponto de vista quantitativo (MUNAKATA, 2007). Atualmente, grande parte do ensino público utiliza o LD escolhido através das coleçóes aprovadas pelo Programa Nacional do Livro Didático

59 Caiapônia fica na microrregiăo Sudoeste do estado de Goiás.

60 Criado em 2007, pelo Instituto Nacional de Estudos e Pesquisas Educacionais Anísio Teixeira (INEP), formulado para medir a qualidade do aprendizado nacional e estabelecer metas para a melhoria do ensino, funciona como um indicador nacional que possibilita o monitoramento da qualidade da Educaçăo pela populaçáo por meio de dados concretos, com os quais a sociedade pode se mobilizar em busca de melhorias. Para tanto, o IDEB é calculado a partir de dois componentes: a taxa de rendimento escolar (aprovaçáo) e as médias de desempenho nos exames aplicados pelo Inep. A Prova Brasil é o exame considerado para o Ensino Fundamental II.

61 Os resultados e metas do IDEB. Disponível em: <ideb.inep.gov.br〉 
(PNLD).62 É importante destacar ainda que, para grande parte do público estudantil, o acesso principal a impressos para a escolarizaçấo e letramento ocorre a partir do LD (BATISTA, 2000), acontecendo fato semelhante em relaçăo aos professores, já que muitos têm, no Manual do Professor, o recurso mais acessível para ampliaçấo de seu conhecimento teórico.

Levando em conta a ligaçăo entre a atividade de ler e interpretar um texto e a sua escolarizaçăo, produzida pelo material didático, este estudo está pautado na vertente qualitativa e se caracteriza como análise documental de caráter qualitativo. A análise documental constitui uma técnica importante na pesquisa qualitativa, tanto no que diz respeito à complementaçấo de informaçōes obtidas por outras técnicas, quanto para desvelar aspectos novos de um tema ou problema (LUDKE; ANDRÉ, 2004).

Para apresentarmos de que forma ocorre a mobilizaçăo dos descritores do Tópico $\mathrm{V}$ no LDP em análise, este artigo está dividido em cinco partes. Começamos apresentando algumas consideraçôes de ordem teórica, trazendo ao leitor nosso entendimento acerca do ato de ler, uma atividade que deve proporcionar àquele que a realiza interaçăo com o material lido, levando à construçăo do sentido e favorecendo a réplica ativa. Na sequência, descrevemos rapidamente a coleçăo de LDP observada, prosseguindo para a análise dos dados, momento em que apresentamos exemplos ilustrativos para os descritores do Tópico V da Matriz de Referência da Prova Brasil e tecemos comentários qualitativos e quantitativos em relaçáo aos exemplos. No final, apresentamos nossas consideraçóes de encerramento, além das referências bibliográficas usadas ao longo deste artigo.

\section{POR QUE FALAR EM LEITURA?}

Falar em leitura mais uma vez e sempre. O tema leitura dificilmente terá esgotadas as possibilidades de sua abordagem, discussăo e problematizaçăo. Lemos desde sempre e a todo momento, mesmo sendo analfabetos. Na escola, a leitura está presente em todas as disciplinas e em todas as práticas escolares. Nessas consideraçóes iniciais, estamos levando em conta todas as leituras possíveis, incluindo aquelas associadas à linguagem nâo verbal.

Para nós, o ato de ler deve ser uma construçâo coletiva, ato reflexivo de um sujeito social. Bakhtin (1981, p. 11) ilustra esta nossa afirmaçăo quando diz que "o indivíduo humano só se torna historicamente real e culturalmente produtivo como parte do todo social". Nesse sentido, seráo as vivências sociais, concretizadas em diferentes espaços, ou esferas de atividade humana (BAKHTIN, 1979), formais ou informais, que tornarăo o indivíduo um sujeito. Esse sujeito năo é um sujeito qualquer, mas o sujeito da interaçăo, do diálogo, do discurso (BAKHTIN/VOLOCHÍNOV, 1981). Bakhtin/Volochínov destaca a importância de se conceber o lugar da alteridade no processo dialógico de construçâo de sentido ao enfatizar, em suas teorias, o caráter social na formaçăo dos indivíduos e o papel da linguagem no desenvolvimento da individualidade e da sociedade.

A questăo do social como inerente ao Homem e à linguagem é discutida por Bakhtin/Volochínov (1981, p. 35) quando é dito que "năo basta colocar face a face dois

62 Tanto o Ensino Fundamental quanto Ensino Médio usam a mesma denominaçâo: PNLD. Em algumas localidades, os apostilados têm sido adotados no lugar dos livros didáticos. 
homo sapiens quaisquer para que os signos se constituam. É fundamental que esses dois indivíduos estejam socialmente organizados, que formem um grupo (uma unidade social)". Da mesma forma, năo basta colocar um objeto a ser lido e um leitor para que a leitura como prática social se efetive. $\mathrm{O}$ ato de ler é materializado discursivamente apenas quando o leitor e o que será lido năo săo tratados como individuais, mas como integrantes de uma unidade social, năo individual. E a escola tem papel fundamental na concretizaçăo disso.

A instituiçâo escolar se destaca enquanto instância oficial de ensino, além de ser a mais importante agência de letramento dentre os espaços sociais, ou esferas de atividade humana, existentes. Desse modo, participa do processo formativo do sujeito, tendo responsabilidade social de formar cidadăos que sejam autores da sua enunciaçâo, capazes de compreender que a linguagem é um evento social, historicamente situado.

Para se abordar a leitura numa perspectiva social, é necessário retomar a construçâo do Ser, que pratica tal ato. É imprescindível que se considere a possibilidade de este Ser, constituído enquanto sujeito-leitor, se perceber historicamente construído, com autonomia para resgatar sentidos produzidos por outro(s) sujeito(s) e também pela possibilidade de poder instaurar novos sentidos àquilo que lê.

Entendemos o ato de ler a partir dos pressupostos da dialogicidade (BAKHTIN/ VOLOCHÍNOV, 1981), em que a construçăo do sentido perpassa pela consciência de que a linguagem năo é apenas um fenômeno físico, mas social, açăo humana que se concretiza a partir das relaçóes de interaçăo. O sujeito leitor consciente, proficiente, se forma no processo interacional, permeado por relaçóes dialógicas, que constituem os discursos materializados através dos gêneros, em cuja constituiçâo estâo entrelaçados o tema, o estilo e a estrutura composicional. ${ }^{63}$

É importante ressaltar que a construçâo da consciência há pouco mencionada está associada à cultura na qual o sujeito se insere e que a linguagem e, consequentemente, o uso dela, estăo intrinsecamente instaurados no processo de construçấo da subjetividade, legitimado como "instância de reconhecimento e de produçăo do saber" (BRANDÅO, 2005, p. 266). Assim, percebe-se que, na busca de construçấo da identidade, o Ser procura a unidade e, na ilusăo de singularidade, muitas vezes se esforça para comprovar que é a fonte dos sentidos, porém a multiplicidade, inerente ao princípio constitutivo da linguagem, instaura o exercício social como condiçâo básica de constituiçăo da subjetividade.

A partir disso, o sujeito passa a interagir com algumas práticas que se estabelecem como educativas e, consequentemente, constitutivas da identidade de sujeito; nâo um sujeito singular, mas constituído a partir de sua singularidade e perpassado pela dialogicidade, pois que, relacionando-se com e pela linguagem, o Ser se desenvolve em diferentes contextos ou culturas, permeado por valores sociais contraditórios possíveis através da interaçâo.

Desse modo, uma proposta de aprendizagem da leitura deve ser construída a partir da apropriaçâo da linguagem por um sujeito social em formaçâo, à medida que este a

63 Năo nos deteremos nesses aspectos porque năo reside aí nosso objetivo. Abordando rapidamente, para Bakhtin (1979), o tema condiz com os conteúdos; a forma composicional possibilita a estrutura comunicativa e o estilo se aplica aos traços da posiçâo do enunciador. 
usa em situaçóes de interaçăo. As açôes realizadas pelo sujeito interativo da aprendizagem permitirăo o desenvolvimento de sua capacidade linguística, de modo que "[...] as relaçóes de interaçáo entre leitores e escritores têm que ser consideradas como atividades de socializaçâo em que eles estejam ocupando uma posiçâo sócio-interacional. O significado daquilo que é lido é construído de forma social" (SILVA, 2000, p. 36).

Cremos que esse deve ser o aprendiz que terá condiçōes de se apropriar da linguagem e, a partir de entăo, revelar maior ou menor autonomia para agir como o sujeito bakhtiniano, capaz de perceber que "a palavra é o material da linguagem interior e da consciência, além de ser elemento privilegiado da comunicaçấo cotidiana, que acompanha toda criaçáo ideológica, estando presente em todos os atos de compreensáo e de interpretaçăo" (SCORSOLINI-COMIN; SANTOS, 2010, p. 08).

É necessário ressaltar que o sujeito do ato de ler está inserido numa sociedade letrada e que a formaçăo na escola deve contribuir para a compreensăo de sua importância no processo histórico e social do qual ele faz parte. Isso possibilita a sua realizaçáo enquanto Ser social em busca de desenvolvimento no sentido dialógico, desenvolvendo a si e ao outro.

Um processo dessa amplitude năo se concretiza de um momento para outro. É necessário que, através de práticas de interaçấo, o sujeito leitor adquira capacidades de desenvolver a leitura autônoma. Defendemos que a escola é o lugar de vivências sociais onde essas práticas podem e devem ser colocadas em uso e onde o sujeito leitor pode adquirir a autonomia necessária para se libertar das amarras impostas pela sociedade manipuladora. Na escola, a leitura é a atividade que muito tem a colaborar nesse sentido, năo sendo apenas uma mera atividade escolar integrante do currículo.

Na sequência do texto, mostraremos se o material didático em análise trabalha na formaçăo desse sujeito, ou se enfatiza mais as práticas escolares comuns de exercitar capacidades de leitura com enfoque mais mecânico.

\section{EM FOCO, A ORGANIZAÇÃO COMPOSICIONAL DO LIVRO ANALISADO}

A coleçăo Tudo é Linguagem aborda os quatro eixos propostos pelos PCN (BRASIL, 1998) para a disciplina de Língua Portuguesa - leitura, produçăo escrita, oralidade e análise linguística. A opçáo, aqui, foi analisar o tratamento dado à leitura e interpretaçáo do texto escrito, considerando que o trabalho com a leitura parte de textos efetivamente materializados em exemplares de gêneros. A coletânea presente no LDP é de textos autênticos, como o Programa Nacional de Livros Didáticos (PNLD). Também pelo fato de que a Prova Brasil mede capacidades da aprendizagem do aluno através de um exame de leitura.

O recorte utilizado engloba o que a coleçăo considerou como trabalho com o eixo leitura, compreendendo os textos principais (aqueles que abrem as unidades) e a interpretaçăo destes contida nas subseçôes: a) Compreensăo inicial; b) A construçăo do texto e c) A linguagem do texto. O número total de atividades de leitura e interpretaçấo do texto escrito de cada volume da coleçâo é o seguinte: 
Tabela 1 - Total de atividades de leitura e interpretação do texto escrito (verbal) na coleção

\begin{tabular}{|cc|}
\hline Volumes da Coleção & Atividades do LDP \\
\hline $6 .^{\circ}$ & 294 \\
\hline $7 .^{\circ}$ & 338 \\
\hline oitavo & 414 \\
\hline $9 .^{\circ}$ & 348 \\
\hline Total & 1394 \\
\hline & Fonte: O autor, 2015 \\
\hline
\end{tabular}

Fonte: O autor, 2015

Consideramos o montante de atividades de leitura e interpretaçăo de texto escrito alto em todos os volumes da coleçâo. Para nós, isso é fator relevante, já que o aluno poderá ter uma boa oportunidade de convivência com ampla quantidade de materiais para leitura e interpretaçấo. Porém, sabemos que entre o que o livro traz e o que acontece de fato na classe existe uma distância enorme, levando em conta que, mesmo que haja disponível um material didático qualificado, o professor que tornará seu uso concreto precisa ser bem formado. Além disso, pode ser que um bom material sequer seja usado pelo professor, que prefere oferecer ao aluno outros materiais que ele, ou a instituiçăo escolar, julga mais eficientes para seus propósitos pedagógicos. Nesse sentido, há que se considerar que quantidade năo significa qualidade.

De acordo com o Manual do Professor (MP), os gêneros apresentados para estudo foram selecionados a partir de "combinaçấo de duas formas de agrupar os gêneros" (p. 8): (i) em funçấo das capacidades de linguagem organizadas de acordo com os aspectos tipológicos (DOLZ; SCHNEUWLY, 2010) - narrar, relatar, expor, argumentar e instruir/ prescrever; (ii) em funçăo da circulaçăo social. ${ }^{64}$

Conforme anunciado no MP (p. 11), no volume do sexto ano há predominância do aspecto tipológico do narrar (gêneros da esfera literária). Cinco (62\%) das oito unidades trabalham com esse aspecto. Cada unidade trabalha com apenas um texto principal. Já no volume do sétimo ano, cujo aspecto tipológico predominante é o relatar (gêneros da esfera jornalística), há, na maioria das unidades, mais de um texto para análise e proposiçâo de atividades. Para melhor visualizaçăo, apresentamos os dados percentuais dos aspectos tipológicos relativos a esses dois volumes ( $6^{\circ}$ e $7^{\circ}$ anos).

64 Os estudos de Bernard Schneuwly, Joaquim Dolz e colaboradores sobre o ensino escolar de gêneros escritos e orais têm sido utilizados no contexto de ensino e aprendizagem de Língua Portuguesa a partir da proposta de agrupamento de gêneros dos autores. Esse grupo de pesquisadores é também conhecido como Grupo de Genebra. 
Tabela 2 - Aspectos tipológicos predominantes nos textos para leitura e interpretação nos volumes do $6^{\circ}$ e $7^{\circ}$ anos

$\begin{array}{cccc}6^{\circ} \text { ano } & \text { Ocorrências } & 7^{\circ} \text { ano } & \text { Ocorrências } \\ \text { Narrar } & 62 \% & \text { Relatar } & 65 \% \\ \text { Relatar } & 13 \% & \text { Narrar } & 27 \% \\ \text { Argumentar } & 13 \% & \text { Argumentar } & 4 \% \\ \text { Descrever ações } & 12 \% & \text { Expor } & 4 \% \\ \text { Expor } & 0 \% & \text { Descrever ações } & 0 \% \\ \text { Total } & 100 \% & \text { Total } & 100 \%\end{array}$

Fonte: O autor, 2015

É perceptível que um dos aspectos tipológicos, dentre os cinco existentes, foi privilegiado em cada série. Tal abordagem, aparentemente năo condiz com a proposta do Grupo de Genebra, que orienta que os aspectos tipológicos devem ser trabalhados de forma contínua e nâo priorizando apenas um deles. Para os pesquisadores, o trabalho com os aspectos tipológicos favorece a abordagem em espiral. Eles dizem que esse tipo de abordagem é mais funcional porque pode garantir ao aluno o aprofundamento do conhecimento a respeito de um gênero ao longo das séries, diferente da abordagem propedêutica, a qual organiza os conteúdos curriculares por ordem de dificuldade, começando pelos menos complexos, passando para os mais complexos, mas sem considerar a progressâo, como é a proposta do Grupo de Genebra.

Como pode ser visto na tabela 2 , apenas um dos aspectos deixou de ser privilegiado em cada um dos volumes analisados aqui. No sexto ano, está ausente o Expor; no sétimo, está ausente o Descrever açôes.

A presença da maioria dos aspectos tipológicos é positiva. A variedade do conjunto de aspectos tipológicos proporcionará também que o conjunto de gêneros seja. Tal fato, no processo de didatizaçăo de objetos de ensino, poderá trazer benefícios ao aluno. Segundo Dolz, Noverraz e Schneuwly (2010), para que a diversidade das capacidades de linguagem seja bem desenvolvida, é necessário que sejam trabalhados com o aprendiz gêneros de agrupamentos diferentes, năo se negligenciando o ensino-aprendizagem da modalidade oral. Outro fator a destacar é que isso poderá permitir que o aprendiz tenha possibilidades de interagir com os diversos gêneros de uso social, diferentemente da abordagem que utilizava a tipologia textual, a qual apresenta, nâo raro, caráter propedêutico.

Apresentamos na sequência tabela com o percentual do oitavo e nono anos.

Tabela 3 - Aspectos tipológicos predominantes nos textos para leitura e interpretação nos volumes do oitavo e nono anos

$\begin{array}{cccc}8^{\circ} \text { ano } & \text { Ocorrências } & 9^{\circ} \text { ano } & \text { Ocorrências } \\ \text { Narrar } & 42 \% & \text { Narrar } & 47 \% \\ \text { Argumentar } & 33 \% & \text { Argumentar } & 35 \% \\ \text { Expor } & 8 \% & \text { Relatar } & 18 \% \\ \text { Relatar } & 0 \% & \text { Expor } & 0 \% \\ \text { Descrever ações } & 0 \% & \text { Descrever ações } & 0 \% \\ \text { Total } & 100 \% & \text { Total } & 100 \%\end{array}$

Fonte: O autor, 2015 
No volume do oitavo ano que, segundo o MP (p. 11), tem o objetivo de priorizar o trabalho com gêneros do aspecto tipológico do expor e do argumentar ocorre, na verdade, predominância do aspecto tipológico do narrar. Também no volume do $9^{\circ}$ ano a ênfase quanto ao aspecto tipológico anunciada pelo MP (p. 11) deveria ocorrer nos gêneros do argumentar, porém, novamente a predominância foi do aspecto tipológico do narrar. Consideramos ser possível que a tradiçăo de trabalhar com textos predominantemente narrativos tenha gerado essa preeminência de textos do aspecto tipológico do narrar, mesmo quando a pretensáo era enfatizar outro aspecto; no caso do oitavo e nono anos, expor e argumentar, respectivamente.

\section{OS DADOS PEDEM ANÁLISE}

Iniciamos esta seçăo dizendo ser importante ressaltar que sua análise se pauta na matriz de referência de Língua Portuguesa da Prova Brasil, a qual é composta por seis tópicos e vinte e um descritores.

Por uma questăo de espaço, năo temos condiçóes de apresentar consideraçôes qualitativas e quantitativas relacionadas a todos os descritores. Assim, apresentaremos, aqui, apenas nossas reflexóes a respeito dos descritores do Tópico $V$ da matriz de referência. Justifica nossa escolha o fato de que aparecem atividades de leitura e interpretaçâo de textos dos seus descritores em três (3) dos quatro (4) volumes da coleçâo em análise, conforme pode ser visualizado na sequência. Isso, no nosso entendimento, oferece ao leitor uma visâo considerável sobre de que forma a coleçáo mobiliza os descritores da avaliaçăo, bem como até que ponto os descritores da avaliaçấo direcionam o trabalho desenvolvido pelo LDP. Justifica, também, a escolha pelo Tópico V o fato de seus descritores terem relaçăo com um nível de leitura que ultrapassa a mera identificaçăo de informaçóes, enfatizando a construçăo de efeitos de sentido, aspecto relevante na formaçăo de leitores autônomos.

Quadro 1 - Volumes da coleção que contemplam o exemplo ilustrativo de cada descritor

\begin{tabular}{c|c}
\multicolumn{1}{c|}{$\begin{array}{c}\text { Matriz de Referência de Língua Portuguesa }{ }^{70} \\
\text { Tópicos }\end{array}$} & Vol.-ex \\
\hline V. Relações entre recursos expressivos e efeitos de sentido & $7 .^{\circ}$ ano \\
\hline D16 Identificar efeitos de ironia ou humor em textos variados. & $6 .^{\circ}$ ano \\
\hline D17 Reconhecer o efeito de sentido decorrente do uso da pontuação e de outras notações & $6 .^{\circ}$ ano \\
\hline D18 Reconhecer o efeito de sentido decorrente da escolha de uma determinada palavra ou \\
expressão
\end{tabular}

Fonte: O autor, 2015

Cada tópico da matriz aborda aspectos de construçâo de capacidades de leitura, a partir de peculiaridades linguísticas e discursivas que necessitam ser desenvolvidas para que o aprendiz construa sua autonomia enquanto leitor competente. Desse modo, a elaboraçấo da matriz segue pressupostos que săo "os Parâmetros Curriculares 
Nacionais [...] e os currículos propostos pelas Secretarias Estaduais de Educaçăo e por algumas redes municipais" (BRASIL, 2011, p. 17).

Os descritores do tópico $V$ estăo relacionados às capacidades que os alunos devem ter para a leitura e o entendimento de um texto, considerando as possíveis relaçôes entre recursos expressivos e efeitos de sentido. Bakhtin (1979) nos diz que a expressividade atribuída a um enunciado varia de acordo com as esferas da comunicaçấo verbal. Diz, ainda, que um enunciado desprovido dessa expressividade é impossível. Atribuir expressividade a um enunciado requer domínios mais complexos. Assim, preparar o aluno para essa tarefa é produtivo.

O autor há pouco mencionado afirma que uma palavra por si năo tem expressividade, năo traz consigo a ironia, por exemplo. Fatores como o contexto de uso, por exemplo, sáo determinantes para que a expressividade passe a fazer parte da palavra e o locutor fique mais perto de alcançar seu intento. Ele fala a respeito da relaçáo que deve haver entre língua e realidade para que a expressividade possa ser possível. Para ele, a expressividade "năo existe nem no sistema da língua nem na realidade objetiva existente fora de nós" (BAKHTIN, 1979, p. 292). Seu lugar é o da relaçăo entre língua e realidade.

A expressividade do enunciado ocorre, ainda segundo Volochínov/Bakhtin (1976), a partir do elo firme que deve existir entre o verbal e o extraverbal - "a entoaçăo genuína, viva, transporta o discurso verbal para além das fronteiras do verbal, por assim dizer" (p. 7).

Dito isto, esclarecemos que consideramos para a escolha dos exemplos ilustrativos aqueles que ofereciam maior relevância em relaçăo aos descritores apresentados aqui. Assim, na sequência, passamos a apresentar nossas consideraçóes a respeito dos descritores do Tópico V.

\section{D16 - identificar efeitos de ironia ou humor em textos variados}

O texto ao qual se refere o exemplo ilustrativo do D16 é um fragmento do relato de experiência de Amir Klink retirado do livro "Mar sem fim: $360^{\circ}$ ao redor da Antártica". No trecho transcrito pelo LD, há duas narrativas: na primeira, "De costas para o ano-novo" (p. 111), Amir Klink relata a tempestade que teve que enfrentar na virada de determinado ano; na segunda, "Textos de viagem" (p. 112), Marina, a esposa de Amir Klink, relata o sentimento de estar em terra firme, acompanhando a aventura do marido, com o qual náo conseguiu se comunicar por uma semana. Quando finalmente se falam por telefone, ela fica sabendo da terrível tempestade enfrentada por ele e comenta esse fato.

Na seçăo Compreensâo Inicial (pp. 113-114) há doze atividades propostas para interpretaçăo do texto. A atividade número 12 (p. 114), abaixo exemplificada, referese ao trecho intitulado "Textos de viagem" e retoma o último parágrafo, propondo as atividades $a$ e b. $O$ exemplo ilustrativo abaixo refere-se à questăo $b$. 
Figura 2 - Exemplo ilustrativo D16 7. ${ }^{\circ}$ ano

\begin{tabular}{|c|c|}
\hline Exemplo ilustrativo - Unidade 4 & D16 Questão 12, p. 114 \\
"No momento o Amyr acaba de reparar os danos decorrentes da tempestade que o "abraçou" no sul da \\
Austrália. Aproveita a calmaria e o tempo bom para amarrar as velas e para "secar suas meias" ". \\
b. Qual a intenção de Marina ao empregar aspas nas expressões "abraçou" e "secar suas meias"? \\
Sugestão: na palavra abraçou pode-se notar certa ironia, pois abraçar é uma ação afetiva, e não houve nada \\
de afetividade no que aconteceu com Amyr. Em "secar suas meias", também se nota ironia, pois provavelmente \\
todas as suas roupas ficaram molhadas com a violência das águas e não apenas as meias. \\
A intenção é mostrar, em tom de brincadeira, de ironia, que a gravidade da história foi maior do que aquilo que o \\
sentido comum dessas palavras expressaria.
\end{tabular}

Fonte: Livro didático Tudo é linguagem $7 .^{\circ}$ ano.

O trabalho com a significaçăo de palavras pressupóe que o aprendiz perceba que é possível dizer uma coisa para significar outra, como comumente ocorre com o uso do recurso irônico, conforme afirmam Sperber e Wilson (1981), citados por Tafarello (2001, p. 86), ao dizer que "uma enunciaçâo irônica é analisada como aquela que diz algo literalmente, mas que significa figurativamente o oposto". Bakhtin (1987) considera a ironia uma forma reduzida do riso. Voloshínov/Bakhtin (1976, p. 15) diz, também, que a ironia "é condicionada por um conflito social: é o encontro, em uma voz, de dois julgamentos de valor personificados e sua interferência recíproca".

Também Possenti (2008) cita Raskin (1987), para quem os estudos linguísticos que tratam do humor e da ironia fixam-se na palavra, enfatizando, principalmente, a ambiguidade, situaçăo em que o vocábulo pode apresentar mais de um sentido. Castro (2005, p. 120) afirma que "a ironia é um caso típico de discurso bivocal. Nela, a palavra tem duplo sentido". ${ }^{65}$

No exemplo em análise, a intençăo da autora é ser um pouco cômica. Na descriçăo do incidente pelo qual Amir Klink passou é bastante claro que este correu risco de morte e que a situaçăo foi tudo, menos cômica. Após a calmaria, a autora se permite até brincar com os fatos ocorridos. É necessário que o aluno leitor construa esse percurso para que perceba o caráter irônico do trecho que finaliza o texto, dando a ele a expressividade necessária para a percepçáo da ironia. O trabalho com essa habilidade é importante porque os discursos que circulam socialmente vêm marcados de ideologias e a linguagem é utilizada para mascarar muitas delas. Nâo custa lembrar que, para Bakhtin/Volochínov (1981, p. 15), a ideologia é inerente às práticas sociais e linguísticas e o signo é ideológico por natureza.

Cabe destacar que a percepçâo do humor e da ironia demonstra que o leitor realiza um roteiro ativo de compreensăo e construçáo de sentidos, o qual parte da palavra e vai além dela, passando pelo sentido. Outro fator a destacar é que esta capacidade de leitura costuma ser trabalhada em LDP a partir de tirinhas, piadas, anedotas e outros gêneros em que a percepçâo do humor ou da ironia poderia ocorrer de forma

65 Castro (2005) diz que, para Bakhtin, discurso bivocal é aquele que surge inevitavelmente a partir de condiçôes de comunicaçâo dialógica. 
mais clara, uma vez que esses textos costumam ser ricos dessa característica. Porém, é importante que os aprendizes percebam que os recursos de humor e ironia podem se fazer presentes em variados gêneros. Também deve ser considerado que o recurso do humor ou da ironia năo se faz presente apenas na materialidade do texto, sendo os aspectos sociohistóricos, associados a eventos de letramento, extremamente relevantes para que haja humor ou ironia.

O fator questionável, a nosso ver, é o número de atividades que mobilizaram esta habilidade na coleçấo: apenas dez atividades em 1394. No volume do sétimo ano, de onde foi retirado o exemplo ilustrativo, temos apenas a ocorrência em questăo. A incidência percentual do D16, neste volume, foi de 0,3\%. Os dados podem ser visualizados na tabela na sequência.

Tabela 4 - Mobilização do D16 - 7. ${ }^{\circ}$ ano

\begin{tabular}{|c|c|c|}
\hline Volume da Coleção Tudo é linguagem & Ocorrência total de atividades & Ocorrências do D16 \\
\hline $7 .^{\circ}$ ano & 338 & 1 \\
\hline TOTAL GERAL & 1394 & 10 \\
\hline
\end{tabular}

Fonte: O autor, 2015

É importante que os aprendizes desenvolvam familiaridade com o humor e a ironia para que possam percebê-los como caracterizadores de estilo em alguns gêneros, seja em situaçóes escolares ou do âmbito social. Também para que percebam que interpretar pressupóe a apreciaçăo de valor, capacidade importante para o desenvolvimento da postura crítica em relaçấo ao posto e ao pressuposto nos textos que circulam socialmente. Ter condiçóes de perceber a ironia e o humor faz com que o aluno vá além do mero exercício de determinar fatores fonéticos ou morfológicos da palavra, por exemplo, valorizando mais o aspecto semântico e o pragmático, que ajudam na construçâo dos efeitos de sentidos esperados.

\section{D17 - Reconhecer o efeito de sentido decorrente do uso da pontuaçăo e de outras notaçōes}

O texto ao qual se refere o exemplo ilustrativo do D17 é a reportagem intitulada "Era uma casa..." sem janela nem quintal (p. 147). O trabalho com os textos da reportagem foi dividido em duas partes. A parte 1 traz o fragmento intitulado "Embaixo da ponte sem número". Depois da subseçâo "Compreensáo Inicial", que traz a proposta de uma atividade oral (p. 151) e doze atividades escritas (pp. 151-152); apresenta-se a transcriçăo da parte 2, intitulada "A casa ideal" (p. 153). Reproduz-se, na parte superior, a fotografia da página do jornal. Logo abaixo, há a transcriçâo dos depoimentos que compôem essa parte da reportagem. Há destaque para as aspas em ambos os textos. Na sequência (p. 154), sâo propostas onze atividades e, em seguida, inicia-se a subseçăo "A linguagem do texto", cujo subtítulo é "Uso de aspas". Seis questóes (pp. 155-156) sâo apresentadas, abordando a utilizaçăo das aspas. A questăo número 3, transcrita na sequência, exemplifica o D17. 
Figura 3 - Exemplo ilustrativo D17 6. ${ }^{\circ}$ ano

Exemplo ilustrativo - Unidade 06

3 No texto A casa ideal, na transcrição dos depoimentos das crianças, as aspas do início de cada fala foram usadas com destaque. Qual teria sido a intenção de quem as representou assim? Provavelmente a intenção foi marcar visualmente o fato de aqueles textos serem falas.

Fonte: Livro didático Tudo é linguagem $6 .^{\circ}$ ano.

A pontuaçăo e sua relaçăo com a construçăo de sentidos, como proposto pelo D17, é uma habilidade importante a ser desenvolvida. No entanto, o que comumente é apresentado nos LDP diz respeito ao aspecto gramatical simplesmente, abordando-se as nomenclaturas e regras de uso (MENDONÇA, 2005). Essa abordagem desconsidera a possibilidade de instauraçăo de sentidos que estes sinais podem adquirir no texto, em virtude de que, ao tomar "a língua como discurso, os recursos gramaticais assumem a funçăo de elementos que contribuem para o estabelecimento de relaçôes de sentido em um texto a partir das intençóes de falantes situados em determinado contexto social" (MENDONÇA, 2005, p. 115). Também Silva (2009) afirma que "a pontuaçăo se materializa junto aos signos linguísticos, corroborando para a constituiçăo de sentidos". Ainda nesse direcionamento, Daleth (1998) enfatiza que a pontuaçấo, apesar de ser objeto de constituiçấo materializado na escrita, possui heterogeneidade, interagindo com os signos linguísticos, favorecendo a construçấo dos sentidos.

O trabalho com a pontuaçáo, no exemplo em análise, foi feito a partir da subseçâo que aborda a linguagem utilizada pelo texto e tem-se um exemplo de discurso citado, com os depoimentos transcritos de forma literal através do uso das aspas. Bakhtin/ Volochínov (1981, p. 147) afirma que "o discurso citado é o discurso no discurso, a enunciaçăo na enunciaçăo, mas é, ao mesmo tempo, um discurso sobre o discurso, uma enunciaçăo sobre a enunciaçăo".

Mendonça (2005) diz que o estudo da pontuaçáo, além de estar ligado à coerência do texto, pode acumular outras funçôes discursivas, como enfatizar alguma intencionalidade e/ou reformular ou justificar certos segmentos. Ou seja, o uso da pontuaçâo vai muito além da identificaçăo de suas funçôes. Nesse quesito, consideramos que o exemplo ilustrativo em análise aborda o proposto pelo D17, que é refletir sobre o efeito de sentido da pontuaçâo, porém a vertente escolhida pode corroborar para uma visâo (autor)itária ao indagar somente sobre a intençăo de quem produziu o texto, visto que a enunciaçăo pressupóe o contexto sócio-histórico situado e năo somente a visáo de quem produziu.

A abordagem das aspas, além do puramente estrutural, pode contribuir para o aprimoramento de capacidades de apreciaçăo e réplica em relaçăo ao texto, pois, perceber que a fala do outro pode ser usada de forma a construir outro enunciado, é perceber que "o mecanismo desse processo năo se situa na alma individual, mas na sociedade" (BAKHTIN/VOLOCHÍNOV, 1981, p. 149).

Para Mendonça (2005), a pontuaçâo deve ser abordada desde os anos iniciais, uma vez que é essencial à aprendizagem da leitura e da escrita. Assim, um trabalho ineficaz com o D17 poderá trazer prejuízos à interpretaçáo de textos que trabalhem com essas habilidades, desfavorecendo a construçâo de sentidos por parte do aprendiz. 
Na sequência, é possível visualizar o quantitativo de atividades que mobilizam esse descritor.

Tabela 5 - Mobilização do D17 no volume do $6^{\circ}$ ano

\begin{tabular}{|c|c|c|}
\hline Volume da Coleção Tudo é linguagem & $\begin{array}{l}\text { Ocorrência total de } \\
\text { atividades }\end{array}$ & $\begin{array}{c}\text { Ocorrências do } \\
\text { D17 }\end{array}$ \\
\hline $\begin{array}{c}6^{\circ} \text { ano } \\
294\end{array}$ & & 16 \\
\hline TOTAL GERAL & 1394 & 47 \\
\hline
\end{tabular}

\section{D18 - Reconhecer o efeito de sentido decorrente da escolha de uma determina- da palavra ou expressăo}

Na unidade 2, o gênero contemplado é Conto Popular em versos, também intitulado pelo LD como Poema Narrativo. Inicialmente, na seçăo "Texto motivador" (p. 45), abordam-se as características do conto popular em versos, como a capacidade de serem contados de memória pelos seus criadores, além do uso de recursos como a musicalidade, ritmo, rima e presença de frases curtas na composiçăo das histórias. Há, ainda, a transcriçăo de um poema-convite, de Pedro Bandeira (sem título, p. 45), bem como fragmentos da obra "Malasaventuras - Safadezas do Malasartes", da Moderna. Nesse poema, a personagem é apresentada como um caipira sabido e arteiro que nấo gosta muito de trabalhar, mas defende os seus amigos que, porventura, sofram algum tipo de injustiça.

Antes de apresentar o texto principal da unidade, "Os porcos do compadre" (pp. 46/47), o LDP caracteriza a personagem, surgida como Pedro Urdemales nas culturas portuguesa e espanhola, conhecida no Brasil como Pedro Malasartes (p. 46). Apresenta, também, um conceito do vocábulo "caipira" e possíveis variaçōes que o termo recebe em diferentes regiōes. Após essa introduçăo, transcreve-se o texto. Em seguida, a subseçăo "Compreensâo inicial" traz oito atividades características das habilidades propostas para essa subseçāo, como localizaçâo e identificaçăo de informaçōes explícitas no texto. Diferentemente do que é comum na estrutura das unidades, há a proposta de um debate e da produçâo de um poema antes das atividades da subseçâo "A linguagem do texto", cujo subtítulo é "Variedades linguísticas". Apresenta-se um texto que conceitua linguagem coloquial e/ou informal e aborda-se a variedade-padrăo para introduzir as 09 atividades propostas para a subseçáo. A atividade abaixo transcrita exemplifica o D18.

Figura 4 - Exemplo ilustrativo D18 6. ano

Exemplo ilustrativo - Unidade 02

D18 Questão 8, pp. 52-53

Releia os dois versos seguintes:

"_ vê se traz dois enxadões"

"e vai ver que foi um só"

Em ambos os versos, foi empregado o verbo ver. Responda:

a. Em que sentido esse verbo foi utilizado em cada uma das situações?

Vê se traz: por favor, traga-me...-vai ver que: é possível que...

Fonte: Livro didático Tudo é linguagem $6^{\circ}$ ano 
Para Bakhtin (1979), nas esferas de atividade humana usamos gêneros específicos que condizem com quem é o locutor e o interlocutor, qual a esfera de produçâo, recepçâo e circulaçāo do gênero. É preciso, também, levar em conta o estilo do gênero, considerando que o locutor năo lida apenas com palavras, "mas com componentes do mundo, com os valores do mundo e da vida" (BAKHTIN, 1979), p. 209). Assim, sáo muitos os elementos a se considerar no momento de usar uma palavra que, neste contexto, é princípio de produçâo e compreensâo dos sentidos.

A palavra, para Bakhtin/Volochínov (1981, p. 15), năo traz em si um sentido, năo pode ser presa a um dicionário, já que o signo é móvel e plurivalente. Dizer isso nos leva a pensar na eficiência de atividades que considerem o efeito de sentido que emerge do uso de uma palavra ou expressâo num dado contexto. Ao usarmos uma palavra, sempre devemos levar em conta a quem nos dirigimos. Daí a relevância em estar sempre atento aos efeitos de sentido que serâo impressos àquilo que foi dito a partir da observaçâo atenta de quem é o interlocutor: "há sempre um interlocutor, ao menos potencial. O locutor pensa e se exprime para um auditório social bem definido" (BAKHTIN/VOLOCHÍNOV (1981, p. 16).

Assim, consideramos bastante pertinente a atividade que vai ao encontro do D18. A leitura é uma prática que pressupóe processamento individual, porém se insere num contexto social. A significaçăo, ao contrário do significado, constitui-se a partir de uma enunciaçáo num determinado contexto (BAKHTIN, 1979). O efeito de sentido será atribuído ao enunciado em virtude do gênero e da esfera, bem como do interlocutor, o qual deve năo apenas conhecer os significados, mas, sobretudo, perceber os efeitos de sentido (as significaçōes) que sâo inerentes a esses enunciados. Năo basta somente identificar o verbo na atividade proposta. Importa perceber que este possibilita diferentes efeitos de sentido, dependendo de alguns fatores, como o contexto de circulaçăo e de recepçấo do gênero em que ele aparece, além de observar se, possivelmente, ele foi escolhido para manter a informalidade e musicalidade, características do poema em prosa.

Perceber estas nuances exige compreensăo do que o locutor pretendeu ao escolher essa palavra e năo outra que poderia perfeitamente substituí-la, mas năo traria ao enunciado a mesma expressividade. A relaçấo com a singularidade é característica do sujeito do discurso, que, ao produzir o enunciado, escolhe como dizer o que quer comunicar. Nesse sentido, cabe ao interlocutor, no processo de compreensăo, contrapor a sua palavra e, sujeito também dos discursos, reconhecer os efeitos de sentido pretendidos pelo locutor (BAKHTIN/VOLOCHÍNOV, 1981).

No volume do $6^{\circ}$ ano, as ocorrências do D18 constam na tabela que segue, bem como o total geral da coleçâo.

Tabela 6 - mobilização do D18 no volume do $6 .^{\circ}$ ano

\begin{tabular}{|c|c|c|}
\hline Volume da Coleção Tudo é linguagem & $\begin{array}{l}\text { Ocorrência total de } \\
\text { atividades }\end{array}$ & $\begin{array}{l}\text { Ocorrências do } \\
\text { D18 }\end{array}$ \\
\hline $\begin{array}{c}\text { 6. }{ }^{\circ} \text { ano } \\
294\end{array}$ & & 16 \\
\hline TOTAL GERAL & 1394 & 48 \\
\hline
\end{tabular}


Desenvolver a habilidade de reconhecer o efeito de sentido de palavras e expressóes utilizadas para a construçăo do texto pode contribuir para que o aluno perceba como é importante a escolha adequada de termos num determinado gênero. Tal reflexăo pode favorecer a ampliaçăo da competência discursiva do aprendiz. Assim, este será capaz de avaliar a relevância do uso de uma palavra em detrimento de outra de acordo com o sentido pretendido, náo só na sua enunciaçăo, mas também na de seus interlocutores, fato fundamental para a interpretaçấo em todos os contextos.

Consideramos que o aspecto questionável foi, mais uma vez, o número de ocorrências: apenas $5 \%$, sendo este o percentual mais significativo de todos os volumes. Atividades como a do exemplo ilustrativo sâo imprescindíveis para que o aprendiz desenvolva a habilidade discutida aqui e possa colocá-la em prática quando a situaçăo exigir.

\section{D19 - Reconhecer o efeito de sentido decorrente da exploraçăo de recursos or- tográficos e/ou morfossintáticos}

O texto ao qual se refere o exemplo ilustrativo é um trecho do romance "As aventuras de Ngunga" (pp. 54-56), de autoria do angolano Pepetela. Para contextualizar o fragmento escolhido, apresenta-se um breve comentário (p. 53) a respeito do enredo e do contexto de produçáo do livro, publicado em forma mimeografada, na floresta de Angola, durante a época de combates contra Portugal pela independência do país. Ngunga é um órfăo de treze anos. Apaixona-se por Uassamba, quarta esposa do velho Chipoya, vendida a ele pelos pais. No trecho proposto, o conflito gira em torno da revolta de Ngunga, que propóe a Uassamba que fuja com ele. Como a moça năo aceita, ele vai embora do povoado.

Na subseçâo "Compreensâo inicial" sâo propostas quatro questôes. Logo após, inicia-se a subseçấo "A linguagem do texto", que apresenta duas divisóes. A primeira traz três atividades que abordam diferenças de uso do português em Portugal e no Brasil; a segunda, intitulada "Elementos de coesâo", contém quatro atividades, das quais transcrevemos a de número 2.

\section{Figura 5 - Exemplo ilustrativo D19 oitavo ano}

2 Observe como foi estabelecida relação entre as orações da sequência descritiva: Os canteiros riam pela boca vermelha das rosas; as verduras cantavam, e a república das asas papeava, saltitando, em conflito com a república das folhas.

Nessa sequência descritiva há uma enumeração de ações que caracteriza o ambiente. Para encadear essa enumeração, foram utilizados dois mecanismos de coesão que mostram simultaneidade das ações: o conectivo e: a pontuação.

a. Como poderia ficar essa sequência se, em vez de utilizar a pontuação, o autor tivesse utilizado apenas o conectivo e? Os canteiros riam pela boca vermelha das rosas e as verduras cantavam e a república das asas papeava, saltitando e em conflito com a república das folhas

b Compare com o texto original, acima, a resposta que você deu ao item anterior. Releia os dois trechos e observe como o ritmo se altera com o uso de um ou de outro recurso de coesão.

Fonte: Livro didático Tudo é linguagem oitavo ano 
Dependendo do gênero, da esfera de circulaçăo e do interlocutor, o locutor dispóe de algumas possibilidades estilísticas de acordo com o efeito de sentido que pretenda imprimir ao texto. $O$ aspecto tipológico do narrar se pauta no domínio do verossímil (DOLZ; SCHNEUWLY, 2010) e, construir um enredo, dependendo do querer-dizer, obriga a opçōes em relaçăo aos recursos linguísticos possíveis.

Dar ênfase, colocar em dúvida, sugerir hesitaçâo ou mesmo alterar o ritmo de uma determinada situaçấo sâo possibilidades expressivas que só se concretizam na enunciaçâo realizada de acordo com o estilo inerente ao gênero. Também sâo nuances que podem ser trabalhadas a partir da exploraçâo de recursos provenientes de estruturas morfológicas, sintáticas ou mesmo ortográficas. Essas escolhas é que permitem que o enunciado expresse emoçăo, juízo de valor, possua vivacidade. Reconhecer essas características, como é a proposta do D19, é possível através de habilidades que o leitor pode desenvolver a partir da convivência com textos.

Atentar para o aspecto estilístico específico do gênero é importante para que o aprendiz perceba a possibilidade de imprimir efeitos de sentido ao enunciado a partir de diferentes recursos que a língua oferece. Tais recursos podem apresentar mais de uma possibilidade de uso, como demonstrado na atividade. Uma sequência descritiva, como a do exemplo ilustrativo, pode exigir efeitos que coadunem sentidos específicos, como velocidade ou ritmo, que é a sugestâo da atividade proposta, o que é positivo destacar ao interpretar o texto.

Mais uma vez, vem à tona a exploraçăo do efeito de sentido decorrente de um uso linguístico. $O$ descritor é bastante relevante por estar associado à avaliaçăo da capacidade de o aluno perceber efeitos de sentido. E a atividade ilustrativa também vai ao encontro dessa possibilidade favorável. Entender que as formas linguísticas por si nâo constituem a enunciaçăo e saber processar isso é indicativo de uma experiência discursiva com o texto. Também é preciso considerar que os elementos nâo verbais da situaçăo sâo relevantes para a construçấo do entendimento acerca do enunciado.

A segunda parte da questáo chama a atençáo do aluno para o ritmo impresso a partir da alteraçáo do elemento textual. Chamar a atençáo para a entonaçáo é importante, já que, dentre outros fatores como, por exemplo, o relacionamento com uma situaçáo social e o conteúdo ideológico, a entonaçăo expressiva afeta a significaçăo (BAKHTIN/ VOLOCHÍNOV,1981). A entonaçâo dá um colorido ao discurso (BAKHTIN, 2010).

Um fato questionável em relaçăo à mobilizaçăo do D19 é a atividade ter ficado tăo somente no aspecto textual/linguístico, deixando de lado as consideraçóes acerca da enunciaçăo. Bakhtin/Volochínov (1981) discute que as categorias morfológicas só têm sentido no interior da enunciaçăo. Já Bakhtin (1979) diz que, fora do enunciado, a entonaçăo expressiva năo existe. A entonaçăo marcada pela questăo vai ao encontro do aspecto gramatical muito mais do que do aspecto expressivo. "Uma oraçăo só atinge a entonaçăo expressiva no conjunto do enunciado" (BAKHTIN (1979, p. 296).

Também nos chama atençâo a baixa ocorrência de atividades com o referido descritor, como é possível visualizar na tabela na sequência. 
Tabela 7 - mobilização do D19 no volume do oitavo ano

\begin{tabular}{|ccc|}
$\begin{array}{c}\text { Volume da Coleção Tudo é } \\
\text { linguagem }\end{array}$ & $\begin{array}{c}\text { Ocorrência total de } \\
\text { atividades }\end{array}$ & $\begin{array}{c}\text { Ocorrências do } \\
\text { D19 }\end{array}$ \\
\hline $\begin{array}{c}8^{\circ} \text { ano } \\
414\end{array}$ & 7 \\
\hline Total geral da coleção & 1394 & 16 \\
\hline
\end{tabular}

No volume do oitavo ano, o valor percentual do $\mathrm{D} 19$ foi de $2 \%$, bem baixo em relaçáo à importância do trabalho com os efeitos de sentido construídos a partir dos recursos ortográficos e/ou morfossintáticos.

\section{PAUSA NA CONVERSA, PORQUE O ASSUNTO NÃO TERMINA AQUI!}

Para finalizar, enfatizamos que o LD, para nós, é um gênero do discurso complexo (BUNZEN e ROJO, 2005), componente do ambiente escolar, utilizado cotidianamente. A escola, principal agência de letramento, precisa oferecer oportunidade para que o aluno desenvolva domínio sobre os gêneros primários e secundários (BAKHTIN/ VOLOCHÍNOV, 1981), possibilitando que este possa ler em qualquer situaçăo. Por isso, julgamos ser importante investigar o ensino e aprendizagem da leitura a partir das atividades apresentadas aos alunos pelo LDP, observando a consonância destas atividades com a Matriz de Habilidades da Prova Brasil para entender, dentre outros aspectos, se a avaliaçấo vem ou năo direcionando a abordagem do LDP aos eixos de ensino.

Os descritores da Prova Brasil foram criados a partir de documentos que orientam a leitura como processo de construçâo de sentidos e todos os vinte e um (21) contemplam habilidades essenciais para uma leitura autônoma. Existem, porém, peculiaridades em relaçăo às capacidades leitoras que náo săo abordadas pelos descritores, inclusive os que abordamos neste artigo. A construçăo da réplica, por exemplo, propiciada a partir de posicionamentos assumidos pelo aprendiz frente a questôes relevantes propostas pelos textos selecionados pela coleçăo năo pode ser classificada em nenhum descritor. Possivelmente, isso se dá pelo fato de que falta maior clareza sobre como avaliar leitura, nâo só no aspecto textual, mas como uma prática discursiva, social e crítica de fato. Talvez novos descritores possam ser pensados, de modo que nâo só a leitura e interpretaçấo de texto possa ser avaliada, mas também os outros eixos propostos pelos PCN (BRASIL, 1998).

Num estudo posterior, pretendemos continuar a apresentar as discussóes iniciadas aqui a partir de conjunto de dados de que dispomos. Acreditamos que isso se torna relevante por conta do grande uso que o material didático tem nas salas de aula brasileiras e pelo fato de a avaliaçáo em larga escala (no caso específico a Prova Brasil) poder ou năo interferir na forma como esse material é pensado pelas editoras. 


\section{REFERÊNCIAS}

BAKHTIN, M. Estética da Criaçăo verbal. Săo Paulo: Martins Fontes, 1979.

Problemas da Poética de Dostoiévski. Rio de Janeiro: Forense Universitária, 2010.

Cultura popular na idade média e no renascimento: o contexto de François Rabelais. Săo Paulo: Hucitec, 1987.

;:VOLOCHÍNOV, V. N. Marxismo e Filosofia da linguagem. Sâo Paulo: Hucitec. 1981.

BATISTA, A. A. G. Um objeto variável e instável: textos, impressos e livros didáticos. In: ABREU, M. (Org.). Leitura, história e história da leitura. Campinas: Mercado de Letras/ ALB, 2000, pp. 529-575.

BORGATTO, A. M. T.; BERTIN, T. C. H.; MARCHEZI, V. L. de C. Tudo é linguagem: língua portuguesa, $5^{\circ}$ a 9ªnos, 2. ed. Săo Paulo: Ática, 2009.

BRANDĂO, H. N. Escrita, leitura, dialogicidade. In: BRAIT, B. (Org.). Bakhtin, dialogismo e construçăo do sentido. Campinas/SP: da UNICAMP, 2005. pp. 265-273

BRASIL. Ministério da Educaçăo e do Desporto. Secretaria de Educaçăo Fundamental. Parâmetros Curriculares nacionais: Terceiro e Quarto Ciclos do Ensino Fundamental Português. Brasília. DF: 1998.

. Ministério da Educaçăo. PDE: Plano de Desenvolvimento da Educaçăo: Prova Brasil: ensino fundamental: matrizes de referência, tópicos e descritores, Brasília: MEC, SEB; Inep, 2011.

BUNZEN, C. e ROJO, R. H. R. Livro didático de Língua Portuguesa como gênero do discurso: autoria e estilo. In: COSTA VAL M. da G. \& MARCUSCHI B. (Orgs.). 0 livro didático de Língua Portuguesa - Letramento, inclusăo e cidadania. Belo Horizonte: Autêntica, 2005, pp. 73-118.

CASTRO, M. L. D. de. A dialogia e os efeitos de sentido irônicos. In: BRAIT, B. (Org.). Bakhtin, dialogismo e construçáo do sentido. 2. ed. Campinas/SP: da UNICAMP, 2005, pp. 119-128.

DAHLET, V. Pontuaçâo, Sentido e Constituiçăo de sentidos. Comunicaçăo apresentada no XLV Seminário do GEL/1997 - Unicamp - Campinas/SP. Sáo José do Rio Preto (SP), 1998, pp. 465-471.

DOLZ, J.; NOVERRAZ, M. \& SCHNEUWLY, B. Sequências didáticas para o oral e a escrita: apresentaçâo de um procedimento. In: SCHNEUWLY, B., DOLZ, J. et al. Gêneros orais e escritos na escola. Campinas: Mercado de Letras, 2010, pp. 95-128.

; \& SCHNEUWLY, B. Gêneros e progressâo em expressăo oral e escrita: elementos para reflexôes sobre uma experiência suíça (francófona).In: SCHNEUWLY, B., DOLZ, J. et al. Gêneros orais e escritos na escola. Campinas: Mercado de Letras, 2010, pp. 41-70.

FREIRE, P. A importância do ato de ler: em três artigos que se completam. 23. ed. Sâo Paulo: Cortez, 1989.

LUDKE, M.; ANDRE, M. E. A. D. Pesquisa em educaçăo: abordagens qualitativas. Săo Paulo: EPU, 2013. 
MENDONÇA, M. R. S. Pontuaçáo e sentido: em busca de parceria. In: DIONísio, Â. P.; BEZERRA, M. A. O livro didático de português: múltiplos olhares. 3. ed. Rio de Janeiro: Lucerna, 2005, pp. 113-125.

MUNAKATA, K. Livro didático: produçâo e leituras. In: ABREU, M. (Org.). Leitura, história e história da leitura. Campinas: Mercado de Letras/ALB, 2007, pp. 577-594.

POSSENTI, S. Os humores da língua: análises linguística de piadas. Campinas : Mercado de letras. 2008.

ROJO, R. H. R. Letramentos múltiplos, escola e inclusáo social. São Paulo: Parábola Editorial, 2009.

SCORSOLINI-COMIN, F; SANTOS, M. A. dos. Bakhtin e os processos de desenvolvimento humano. Revista Brasileira Crescimento Desenvolvimento Humano. vol.20, n.3, Sáo Paulo, 2010. Disponível em: ‘http://pepsic.bvsalud.org/scielo.php?pi$\mathrm{d}=$ S010412822010000300009\&script=sci_arttext >. Acesso em: 10 nov. 14 .

SILVA, S. R. da. Leitura: análise da reaçấo dos alunos perante o modelo sócio-interacional. 2000. 216 f. Dissertaçâa. Mestrado em Linguística: Universidade Federal de Uberlândia, 2000.

SILVA, E. T. da. Criticidade e leitura: ensaios. 2. ed. Săo Paulo: Global, 2009.

TAFARELLO, M. C. M. A polifonia irreverente do texto de humor político. 2008. $233 f$. Tese (Doutorado) Universidade Estadual de Campinas, Campinas, 2008.

VOLOCHÍNOV, V.; BAKHTIN, M. 0 discurso na vida e o discurso na arte. Sobre poética sociológica. Traduçăo: do inglês: Carlos Alberto Faraco e Cristovăo Tezza, 1976. 